\title{
EFFECTS OF DIETARY ADMINISTRATION OF BACILLUS PROBIOTICS ON THE NON-SPECIFIC IMMUNE RESPONSES OF TINFOIL BARB, BARBONYMUS SCHWANENFELDII (ACTINOPTERYGII: CYPRINIFORMES: CYPRINIDAE)
}

\author{
Khalil ESLAMLOO ${ }^{1}$, Sobhan R. AKHAVAN ${ }^{2}$, and Morgane A. HENRY ${ }^{3 *}$ \\ ${ }^{1}$ Fisheries Department, Faculty of Natural Resources, \\ University of Guilan, Sowmeh Sara, Guilan, Iran, keslamloo@mun.ca \\ ${ }^{2}$ Department of Fisheries, Faculty of Marine Natural Resources, Khoramshahr University of Marine Science \\ and Technology,PB No: 669, Khorramshahr,Iran, sobhan_akhavan@yahoo.com \\ ${ }^{3}$ Hellenic Centre for Marine Research, Institute of Aquaculture, \\ Aghios Kosmas, 16777 Elliniko, Athens, Greece,morgane@ath.hcmr.gr
}

Eslamloo K., Akhavan S.R., Henry M.A. 2013. Effects of dietary administration of Bacillus probiotics on the non-specific immune responses of tinfoil barb, Barbonymus schwanenfeldii (Actinopterygii: Cypriniformes: Cyprinidae). Acta Ichthyol. Piscat. 43 (3): 211-218.

\begin{abstract}
Background. Probiotics are known as immunostimulants as well as growth and survival promoters in fish, but despite the plethora of studies on the effect of probiotics on the fish non-specific immune responses, very few information is available for ornemental fish. Thus, this study was carried out to investigate the effects of shortterm dietary administration of Bacillus probiotics (B. subtilis and B. licheniformis) on the immune responses of tinfoil barb, Barbonymus schwanenfeldii (Bleeker, 1854).

Materials and methods. Three experimental diets were prepared by supplementing the diets with different concentrations of probiotics including 0 (Control), $1 \times 10^{4}$ (T1) and $1 \times 1330^{6}(\mathrm{~T} 2) \mathrm{CFU} \cdot \mathrm{g}^{-1} \mathrm{diet}_{\text {. Tinfoil barb }}$ weighing $16.20 \pm 0.13 \mathrm{~g}$ were fed different diets for 15 days. At the end of the experiment, blood samples were collected in order to estimate the hematological (total protein, albumin, and globulin) and immune (total antiprotease, plasma peroxidase, and bactericidal activities ) parameters.

Results. The plasma total protein, albumin, and globulin of fish were not affected by dietary probiotics. A sixfold increase in the plasma total antiprotease activity of fish fed $1 \times 10^{6} \mathrm{CFU} \cdot \mathrm{g}^{-1}$ diet was observed. Moreover, the plasma peroxidase and bactericidal activities of fish significantly increased in T2 treatment compared to control. On the other hand, plasma natural haemolytic complement and lysozyme activities did not significantly vary between diets although the highest level of these parameters was observed in the probiotic treatments.

Conclusion. This study showed the ability of dietary probiotics to enhance some innate immune responses of tinfoil barb especially after a 2 -week administration of $1 \times 10^{6} \mathrm{CFU} \cdot \mathrm{g}^{-1}$ diet (T2). Further study should focus on the effect of this dietary bacterial concentration on the fish response to bacterial and parasitical challenges in order to test its potential protective effect against the common pathogens of tinfoil barb.
\end{abstract}

Keywords: Ornamental fish, immunostimulant, innate immunity, Bacillus subtilis, Bacillus licheniformis

\section{INTRODUCTION}

The aquaculture- and aquarium fishes are sensitive to stress and diseases. Preventive methods to avoid diseases and loss of fish include vaccination, but vaccines are not available against all pathogens and especially against parasites. This lack of vaccines together with the environmental impact of extensive use of therapeutic agents such as antibiotics justify the increasing demand for efficient nonspecific immunostimulants for aquaculture (Sakai 1999, Bricknell and Dalmo 2005). Immunostimulants, which are biological and synthetic compounds, can modulate the immune responses and disease resistance of fish by enhancing the fish non-specific immunity (Sakai 1999). According to FAO definition, probiotics are "live microorganisms, which when administered in adequate amounts confer a health benefit on the host" (Anonymous 2002). Dead cells are also known as probiotic when the immunomodulation feature of probiotics are concerned (Adams 2010); thus, probiotics are alive or dead beneficial bacteria, which can control pathogens through improving the immune responses of hosts (Irianto and Austin 2002, Aly et al. 2008, Qi et al. 2009, Adams 2010,

\footnotetext{
${ }^{*}$ Correspondence: Dr M.A. Henry, Hellenic Centre for Marine Research, Aghios Kosmas, 16777 Elliniko, Athens, Greece. Tel:+302109856736. Fax: +302109829239, e-mail: morgane@ath.hcmr.gr.
} 
Ringø et al. 2012). The dietary application of probiotics has numerous beneficial effects on fish including growth promotion through the modulation of the host's metabolic functions possibly enhancing the fish digestive activity and synthesis of vitamins (Gatesoupe 2008, Kesarcodi-Watson et al. 2008, Ringø et al. 2012), pathogen exclusion through the modification of the gut microflora and disease resistance through the enhancement of fish immunity (Aly et al. 2008, Gatesoupe 2008, Nayak 2010, Ringø et al. 2012). Such exogenous microbes antagonistic to pathogens are termed biocontrol agents (Merrifield et al. 2010, Maeda et al. 1997). There is therefore a growing use of probiotics in aquaculture to control fish diseases (Gatesoupe 1999, Kumar et al. 2008). Both alive and dead cells can be used as probiotic in order to improve fish welfare, albeit viable live probionts seems better than the non-viable cells (Ringø 2012), for they can safely and more strongly enhance immunity and do not cause any infection or disease in fish. Fish immunomodulation by probiotics depends however on the type of probiotic strain, the fish species, and their genetic makeup and the feeding duration and dosage (Nikoskelainen et al. 2003, Salinas et al. 2005, Kim and Austin 2006, Son et al. 2009, Rodríguez et al. 2003). During the last 10 years, many investigations conducted on the dietary application of probiotics in aquaculture have focused on Bacillus spp. and Lactobacillus spp. (Wang et al. 2008, Qi et al. 2009, Nayak 2010, Merrifield et al. 2010, Kiron 2012) and one of the most popular probiotics used in aquaculture are the Bacillus strains (Qi et al. 2009, Nayak 2010). In particular, Bacillus probiotics have been shown to possess antimicrobial and immunomodulatory activities in host (Cutting 2011). In fish, B. subtilis and $B$. licheniformis have been reported to elevate the immune responses and disease resistance of rainbow trout, Oncorhynchus mykiss (Walbaum, 1792), and Indian major carp_rohu, Labeo rohita (Hamilton, 1822) (see Kim and Austin 2006, Kumar et al. 2008).

Although a large number of studies have been conducted to investigate the effects of probiotics on the immune responses of aquaculture fish, few studies have been carried out on the influence of the dietary administration of probiotics on the immunity of ornamental fish. The culture of ornamental fish is an important activity in several Asian countries. Since there is a globally rising trend towards aquarium fish, ornamental fish culture industry is steadily growing worldwide (Yanar et al. 2008). Cyprinidae is a dominant family in this industry and tinfoil barb, Barbonymus schwanenfeldii (Bleeker, 1854), is one of the most important cyprinid species, widely reared in South East Asia. However, this species is commercially used in warm-water aquaculture industry for integrated farming with other cyprinids (Bailey and Cole 1999). This species can be carrier of protozoan and parasitic nematodes (Gante et al. 2008) and is also sensitive to the white spot disease or other parasitic infections, ulcerative rhabdovirus syndrome, and various bacterial diseases (Bassleer 1997). Immunostimulation of this fish may prevent disease occurrences, thus reducing the economic cost and environmental impact of the extensive use of therapeutics. In the majority of previous studies, Bacillus probiotics and particularly $B$. subtilis have been well established to enhance the immune responses of cyprinids and other fish with similar digestive tract (Nayak et al. 2007, Aly et al. 2008, Kumar et al. 2008, Kiron 2012). Interestingly, a study in gilthead seabream, Sparus aurata L., showed that the use of multispecies probiotics had better immunomodulating capacity than dietary administration of monospecies probiotics (Salinas et al. 2005). Several fish studies showed that a 10 to 14 day administration period of dietary probiotics was optimal for fish immunostimulation (Rodríguez et al. 2003, Salinas et al. 2005, Sharifuzzaman and Austin 2009, Son et al. 2009). It seems that the influence of probiotics can be evidenced even after short-term administration. However, various studies showed that efficient probiotic species and dietary dosage vary between fish species. Therefore even commercially available probiotics should be checked in order to determine optimal probiotic species, dosage, and duration of administration for each fish species of interest. Hence, the presently reported study was aimed to investigate the effects of short-term (2 weeks) dietary administration of a mixture of Bacillus subtilis and B. licheniformis on the non-specific immune responses including antiproteases, peroxidase, lysozyme, natural haemolytic complement, and bactericidal activities as well as plasma protein, albumin, and glubolin of tinfoil barb.

\section{MATERIALS AND METHODS}

Experimental design and test diets. The probiotic containing spores of Bacillus subtilis and B. licheniformis were obtained from Protexin Co. (Iran-Nikotak). The colony forming units (CFU) of Bacillus probiotics were checked by culturing probiotics on Tryptic Soy Agar (TSA) (Rengpipat et al. 1998). Three experimental diets with different levels of probiotics concentration including 0 (control), $1 \times 10^{4}(\mathrm{~T} 1)$, and $1 \times 10^{6}(\mathrm{~T} 2) \mathrm{CFU} \cdot \mathrm{g}^{-1}$ diet were prepared.

Briefly, according to manufacturer's procedure, probiotics were added to sterile water $\left(10 \mathrm{~g} \cdot \mathrm{L}^{-1}\right)$ and allowed to incubate for $8 \mathrm{~h}$ at $37^{\circ} \mathrm{C}$. Then, the different levels of probiotics were sprayed on a commercial pelleted diet containing fishmeal, soybean mean, corn and wheat flour, shrimp, fish oil, soybean oil, carotenoids, monophosphate calcium, vitamin, and mineral premix (Energy 4EF3001, Thailand; moisture $12 \%$, crude protein $41 \%$, crude fat $6 \%$ and fiber $2 \%$ ) and dried at $40^{\circ} \mathrm{C}$, in an incubator for $6 \mathrm{~h}$ and kept at $4{ }^{\circ} \mathrm{C}$ until use. The experimental diets were prepared every 3 days.

Fish and feeding trial. Prior to the beginning of the experiment, the fish were acclimatized to the control diet (same to aforementioned commercial diet: moisture 12\%, crude protein $41 \%$, crude fat $6 \%$ and fiber $2 \%$ ).and rearing conditions for two weeks. Ninety juvenile tinfoil barb weighing $16.20 \pm 0.13 \mathrm{~g}$ were randomly distributed into 9 rectangular glass aquaria $(50 \times 30 \times 35 \mathrm{~cm}, 52 \mathrm{~L})$ filled with dechlorinated tap water with adequate aeration and 
filtration at $12 \mathrm{~L}: 12 \mathrm{D}$ photoperiod. Twenty percent of the water contained in each tank was replaced with fresh, dechlorinated tap water every day. This study was performed in triplicate (10 fish per aquarium; 3 aquaria per dietary treatment). The fish in each treatment were fed experimental diets to apparent satiation twice a day at $0800 \mathrm{~h}$ and $1600 \mathrm{~h}$ for 15 days. The fish were starved for $24 \mathrm{~h}$ before sampling. Water quality parameters were monitoredduring the experiment (temperature $26.90 \pm$ $0.14^{\circ} \mathrm{C}$, dissolved oxygen $6.3 \pm 0.3 \mathrm{mg} \cdot \mathrm{L}^{-1}$, ammonia $0.140 \pm 0.004 \mathrm{mg} \cdot \mathrm{L}^{-1}$, nitrites $0.059 \pm 0.060 \mathrm{mg} \cdot \mathrm{L}^{-1}$, hardness $193.4 \pm 13.2 \mathrm{mg} \cdot \mathrm{L}^{-1}$, and $\mathrm{pH} 7.3 \pm 0.4$ ). Oxygen and temperature were assayed using an oximeter (WTW oxi 33oi, Weilheim, Germany), whereas the measurement of other water quality parameters followed the methods of Tripathi and Govil (2001).

Sampling. After 15 days of feeding trial, blood samples were collected to estimate the immunological parameters of fish in various treatments. Six fish from each replicate were netted and anaesthetised by $400 \mathrm{mg} \cdot \mathrm{L}^{-1}$ of clove powder. Then, $0.5-0.6 \mathrm{~mL}$ of blood samples were collected by caudal vein puncture using a $2-\mathrm{mL}$ heparinized syringe. The blood samples were immediately placed in $2 \mathrm{~mL}$ tubes and the plasma was separated from blood by centrifugation at $3000 \times g$ for $10 \mathrm{~min}$. The plasma of two fish in each replicate waspooled, giving a total of three pooled plasma samples for each replicate aquarium; thus, 9 samples per dietary treatment were prepared. The plasma samples were stored at $-70^{\circ} \mathrm{C}$ until analysed.

Total protein, albumin, and globulin. Plasma total protein quantity was determined using a kit (Bio-Rad Laboratories $\mathrm{GmbH}$, Munich, Germany) with bovine serum albumin as a standard (Bradford 1976). Plasma albumin was detected at $620 \mathrm{~nm}$ (Quantichrom ${ }^{\mathrm{TM}}$ BCG Albumin Assay Kit) (Nicholson et al. 2000). Additionally, the content of total globulin was calculated by subtracting albumin from total protein (Kumar et al. 2005).

Plasma antiproteases activity. Total antiprotease activity was assayed as an indicator of the plasma capacity for inhibiting trypsin activity (Magnadóttir et al. 1999). The antiprotease activity was expressed as the percentage of trypsin inhibition (Zuo and Woo 1997).

Peroxidase activity. Plasma Peroxidase activity was measured using 3,3',5,5'-tetramethylbenzidine hydrochloride (TMB) and hydrogen peroxide as peroxidase enzyme substrate (Quade and Roth 1997). Briefly, $15 \mu \mathrm{L}$ of plasma was diluted with $50 \mu \mathrm{L}$ of Hank's buffered salt solution (HBSS) without $\mathrm{Ca}^{+2}$ or $\mathrm{Mg}^{+2}$ in flat-bottomed 96-well plates. Then, $100 \mu \mathrm{L}$ of $0.1 \mathrm{mM}$ TMB and $2.5 \mathrm{mM} \mathrm{H}_{2} \mathrm{O}_{2}$ were added and incubated for $2 \mathrm{~min}$. The colour-developing reaction in plasma samples was stopped after 2 min by adding $50 \mu \mathrm{L}$ of $2 \mathrm{M}$ sulphuric acid and the optical density (OD) was read at $450 \mathrm{~nm}$ using a microplate reader (Stat Fax-2100, USA). Wells without plasma were used as blanks. The peroxidase activity was defined as one unit of peroxidase producing an absorbance change of 1 OD.

Plasma lysozyme activity. Plasma lysozyme activity was assayed based on the turbidimetric method (Cha et al. 2008).
Natural haemolytic complement activity. The natural haemolytic complement activity was determined using sheep red blood cells (SRBC) as target cells (Ortuno et al. 1998) with slight modifications. SRBC were washed and resuspended at $3 \%(\mathrm{v} / \mathrm{v})$ phenol red-free Hank's balanced salt solution (HBSS) containing $\mathrm{Mg}^{2+}$ and $10 \mathrm{mM}$ EGTA (EGTA-HBSS). Aliquots of $100 \mu \mathrm{L}$ plasma were serially diluted in EGTA-HBSS and were added to $100 \mu \mathrm{L}$ of SRBC After a $1-\mathrm{h}$ incubation at $22^{\circ} \mathrm{C}$ and centrifugation, the concentration of haemoglobin in the supernatants was assessed by measuring the absorbance at $450 \mathrm{~nm}$ in a microplate reader (Stat Fax-2100, USA). Maximum and spontaneous haemolysis were obtained by adding $100 \mu \mathrm{L}$ of distilled water or HBSS to $100 \mu \mathrm{L}$ samples of SRBC, respectively. The lysis curve for was determined for each sample on a $\log _{10}-\log _{10}$ scaled graph. The amount of plasma complement producing 50\% haemolysis (ACH50) was obtained and results were expressed as ACH50 units $\mathrm{mL}^{-1}$. Plasma bactericidal activity. Plasma bactericidal activity against Aeromonas hydrophila, which is a common fish pathogen, was measured following the method of Rao et al. (2006). Fish plasma was incubated with the bacteria then plated on agar. Colony forming units (CFU) were counted and bactericidal activity was deduced.

Statistical analyses. Statistical analyses were performed using the software SPSS 15.0 (Chicago, IL, USA). The normality of distribution of variables was tested by Kolmogorov-Smirnov test. The homogeneity of variances was tested using the Levene's $F$ test. Differences between various treatments were analyzed by one-way ANOVA, followed by Tukey's post hoc test. Differences were considered statistically significant when $P \leq 0.05$. All experimental data was expressed as mean $\pm \mathrm{SE}$.

Ethical issues. Despite the fact that no ethical regulation exist in Irak, animals were handled with care and their welfare was taken into account during samplings when fish were properly anaesthetised.

\section{RESULTS}

After 15 days of feeding trial, plasma total protein $(P=0.741)$, albumin $(P=0.649)$, and total globulin $(P=0.711)$ of fish did not significantly vary between treatments (Fig. 1). However, the highest levels of plasma protein and albumin were seen in $\mathrm{T} 1$ and $\mathrm{T} 2$ groups ranging between 3.72 to 3.95 and 1.37 to $1.42 \mathrm{~g} \cdot \mathrm{dL}^{-1}$ for protein and albumin respectively.

At the end of the experiment, some non-specific immune responses were significantly altered by dietary probiotics. The amount of plasma trypsin inhibition was higher in fish fed Bacillus probiotics compared to control. Indeed, the amount of plasma trypsin inhibition in $\mathrm{T} 2$ group increased to $60 \%$ in comparison with control group where $10 \%$ inhibition was obtained $(P=0.004)$ (Fig. 2).

The amount of peroxidase activity significantly increasedin fish fed with $1 \times 10^{6} \mathrm{CFU} \cdot \mathrm{g}^{-1} \operatorname{diet}(\mathrm{T} 2) \mathrm{com}-$ pared to control and T1 groups $(P<0.001$; Fig. 3$)$.

The lysozyme activity of fish fed Bacillus probiotics was higher than that in control group. It increased from 
$19.0 \pm 2.1 \mathrm{U} \cdot \mathrm{mL}^{-1}$ in control group to $28.3 \pm 3.5 \mathrm{U} \cdot \mathrm{mL}^{-1}$ in $\mathrm{T} 1$ and to $26.6 \pm 4.7 \mathrm{U} \cdot \mathrm{mL}^{-1}$ in $\mathrm{T} 2$. However, significant differences were not observed between treatments $(P=0.086$; Fig. 4).
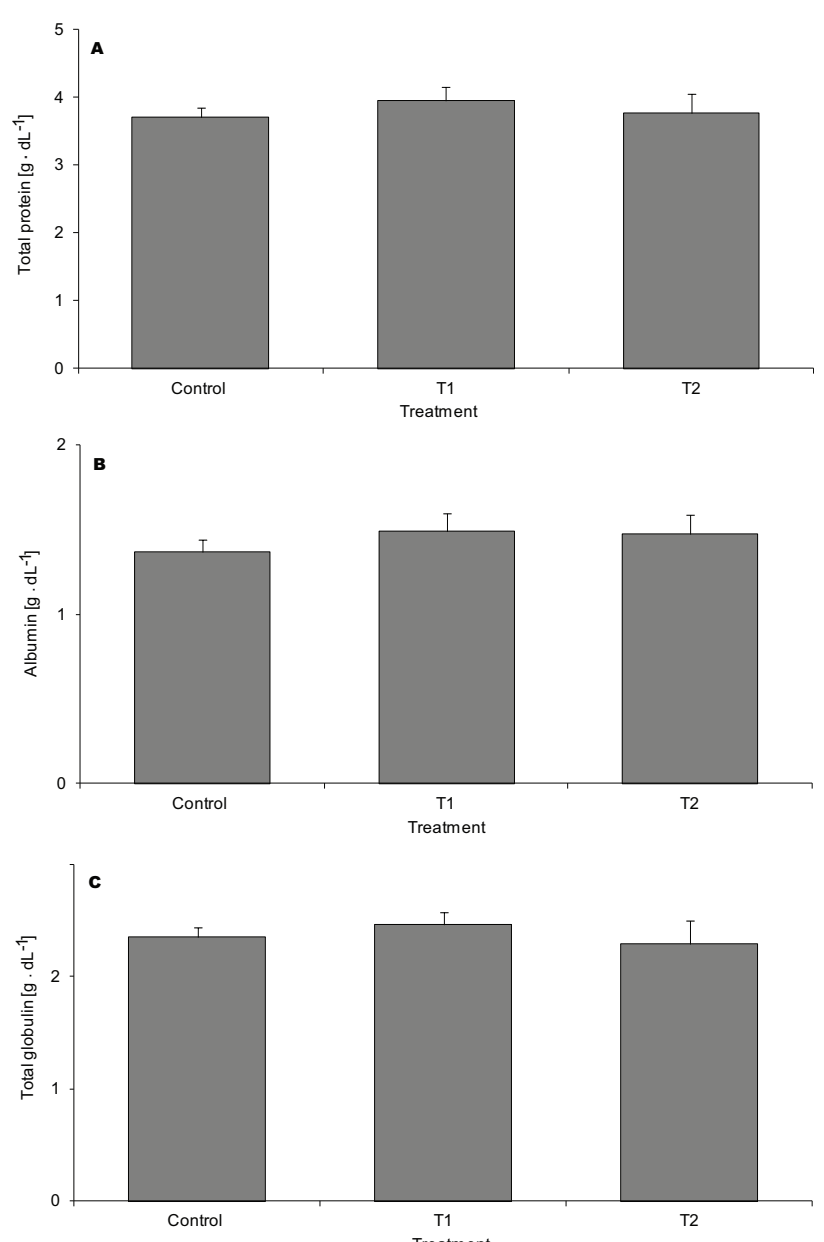

Fig. 1. Plasma total protein (A), albumin (B) and globulin (C) levels of tinfoil barb, Barbonymus schwanenfeldii, fed different levels of dietary probiotics (control, $0 \mathrm{CFU} \cdot \mathrm{g}^{-1} \operatorname{diet} ; \mathrm{T} 1,1 \times 10^{4} \mathrm{CFU} \cdot \mathrm{g}^{-1} \operatorname{diet} ; \mathrm{T} 2$, $1 \times 10^{6} \mathrm{CFU} \cdot \mathrm{g}^{-1}$ diet) for 15 days; Data are presented as mean $\pm \mathrm{SE}(n=9)$; No significant difference $(P>0.05)$ was observed between treatments

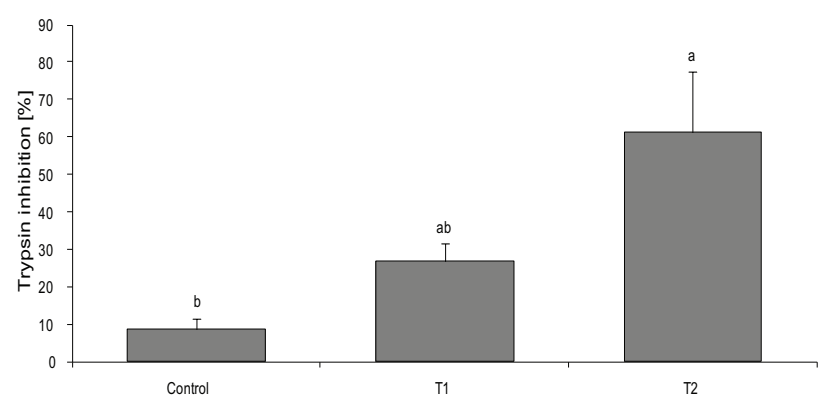

Fig. 2. Plasma trypsin inhibition activity of tinfoil barb, Barbonymus schwanenfeldii, fed different levels of dietary probiotics (control, $0 \mathrm{CFU} \cdot \mathrm{g}^{-1}$ diet; $\mathrm{T} 1,1 \times 10^{4}$ $\mathrm{CFU} \cdot \mathrm{g}^{-1}$ diet; $\mathrm{T} 2,1 \times 10^{6} \mathrm{CFU} \cdot \mathrm{g}^{-1}$ diet) for 15 days; Data are presented as mean $\pm \mathrm{SE}(n=9)$; Bars with different letters were significantly different $(P<0.05)$
The amount of plasma natural haemolytic complement activity (ACH50), ranging between 30.5 and $39 \mathrm{U} \cdot \mathrm{mL}^{-1}$, did not change significantly between groups, in spite of the fact that the highest level of ACH50 was seen in T1 treatment $(P=0.091$; Fig. 5).

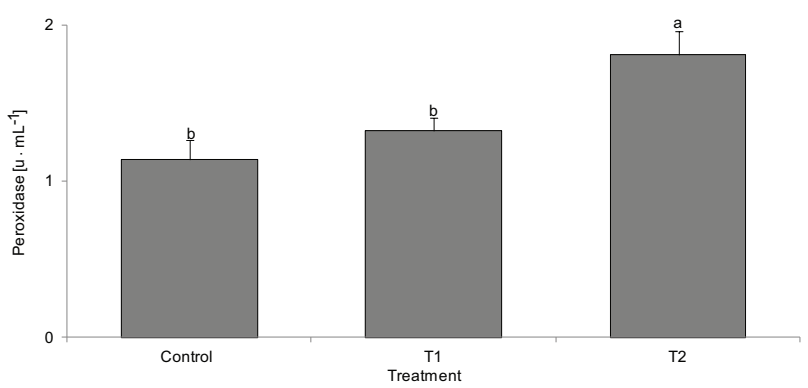

Fig. 3. Plasma peroxidase activity of tinfoil barb, Barbonymus schwanenfeldii, fed different levels of dietary probiotics (control, $0 \mathrm{CFU} \cdot \mathrm{g}^{-1}$ diet; $\mathrm{T} 1,1 \times 10^{4}$ $\mathrm{CFU} \cdot \mathrm{g}^{-1}$ diet; $\mathrm{T} 2,1 \times 10^{6} \mathrm{CFU} \cdot \mathrm{g}^{-1}$ diet) for 15 days. Data are presented as mean $\pm \mathrm{SE}(n=9)$ : Bars with different letters were significantly different $(P<0.05)$

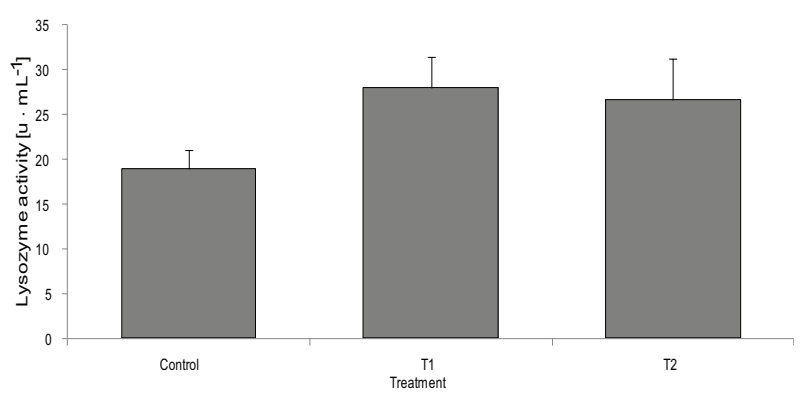

Fig. 4. Plasma lysozyme activity of tinfoil barb, Barbonymus schwanenfeldii, fed different levels of dietary probiotics (control, $0 \mathrm{CFU} \cdot \mathrm{g}^{-1}$ diet; T1, $1 \times$ $10^{4} \mathrm{CFU} \cdot \mathrm{g}^{-1}$ diet; T2, $1 \times 10^{6} \mathrm{CFU} \cdot \mathrm{g}^{-1}$ diet) for 15 days; Data are presented as mean $\pm \mathrm{SE}(n=9)$; No significant difference $(P>0.05)$ was observed between treatments

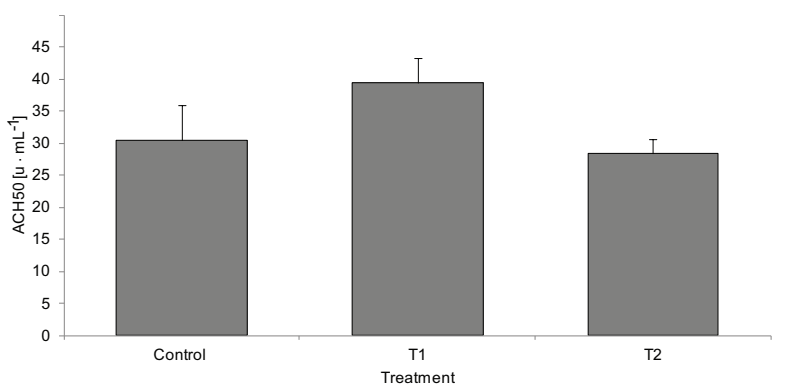

Fig. 5. Plasma natural haemolytic complement activity (ACH50) of tinfoil barb, Barbonymus schwanenfeldii, fed different levels of dietary probiotics (control, 0 $\mathrm{CFU} \cdot \mathrm{g}^{-1}$ diet; $\mathrm{T} 1,1 \times 10^{4} \mathrm{CFU} \cdot \mathrm{g}^{-1}$ diet; $\mathrm{T} 2,1 \times 10^{6}$ $\mathrm{CFU} \cdot \mathrm{g}^{-1}$ diet) for 15 days; Data are presented as mean $\pm \mathrm{SE}(n=9)$; No significant difference $(P>$ 0.05 ) was observed between treatments 
The plasma bactericidal activity of fish in T2 group significantly increased compared to control group with significantly less viable bacteria in contact with the sera of fish fed Bacillus at $1 \times 10^{6} \mathrm{CFU} \cdot \mathrm{g}^{-1}$ diet, $180 \mathrm{CFU}$ compared to $207 \mathrm{CFU} \cdot \mathrm{g}^{-1}$ in control fish $(P=0.041$; Fig. 6). Although the same tendency was observed in T1 group, the difference with the control group was not significant (Fig. 6). The number of $\mathrm{CFU} \cdot \mathrm{g}^{-1}$ in negative control samples (using PBS instead of plasma) was $335 \pm 16$.

\section{DISCUSSION}

Proteins having a key role in physiological and immunological systems are the main serum components (Kumar et al. 2005). In this study, plasma total protein, albumin, and total globulin did not significantly vary between treatments. However, the highest levels of these parameters were observed in probiotic treatments. Similarly, the plasma proteins of Nile tilapia, Oreochromis niloticus (L.), did not significantly change after rearing in water containing Enteroccus faecium $1 \times 10^{7} \mathrm{CFU} \cdot \mathrm{mL}^{-1}$ (Wang et al. 2008). Adding Bacillus probiotics to rearing water of tilapia led to an increase in plasma total protein, yet this variation was not seen for plasma albumin and total globulin (Zhou et al. 2010). On the other hand, dietary administration of B. subtilis appreciably increased serum total protein, albumin, and total globulin in Indian major carp-rohu, Labeo rohita, and serum total protein in rainbow trout, Oncorhynchus mykiss (see Nayak et al. 2007, Newaj-Fyzul et al. 2007). Therefore, it seems that the influence of probiotics on the elevation of serum proteins varied between species and bacterial strains and also depends on the duration of administration. The variations of the total protein concentration may reflect variations of acute phase response (APR) with an equilibrum between production of acute phase protein (positive APP) and decline of other acute phase proteins (negative APP) (Brunt et al. 2008).

The serum antiprotease activities of hosts, which mainly include $\alpha_{1}$-antiprotease, $\alpha_{2}$-antiplasmin, and $\alpha_{2}$-macroglobulin, are identified as anti-enzymes that possess a capacity for delaying or inhibiting pathogens attacking the body through proteolytic enzyme secretion (Magnadóttir 2006). The antiprotease activity is known to be highly influenced by immunization or infection (Magnadóttir 2006). In the present study, the plasma antiprotease activity markedly increased in fish fed Bacillus probiotics; in other words, the amount of this anti-enzyme in T2 treatment was six-fold greater than that of the control group. Similarly, the activity of serum antiprotease in rainbow trout doubled after two weeks of oral administration of commercial probiotics, but these significant differences were not reported for either shorter (one week) or longer ( 3 and 4 weeks) times of administration (Sharifuzzaman and Austin 2009). Also similar to our study, total antiprotease activity in rainbow trout significantly increased after two weeks of oral administration of B. subtilis (see Newaj-Fyzul et al. 2007). The results of this study showed that the oral administration of

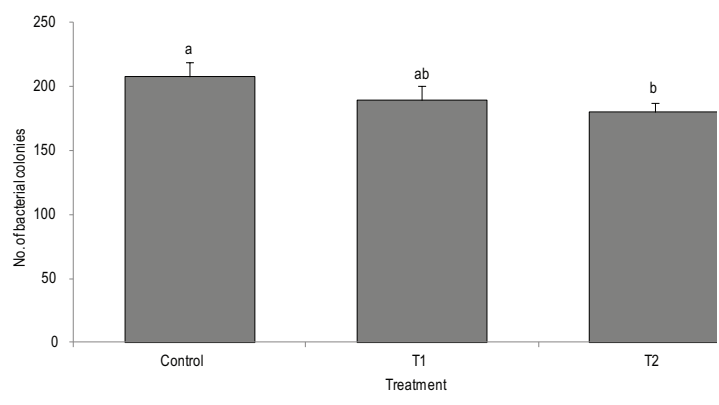

Fig. 6. Plasma bactericidal activity of tinfoil barb, Barbonymus schwanenfeldii, fed different levels of dietary probiotics (control, $0 \mathrm{CFU} \cdot \mathrm{g}^{-1}$ diet; $\mathrm{T} 1,1 \times 10^{4}$ $\mathrm{CFU} \cdot \mathrm{g}^{-1}$ diet; $\mathrm{T} 2,1 \times 10^{6} \mathrm{CFU} \cdot \mathrm{g}^{-1}$ diet) for 15 days; Data are presented as mean $\pm \mathrm{SE}(n=9)$; Bars with different letters were significantly different $(P<0.05)$

Bacillus probiotics could significantly increase the antiprotease activity of this species, thus protecting the fish against the proteolytic activity of potential pathogens.

In the presently reported research, the amount of plasma peroxidase activity significantly increasedin fish fed $1 \times 10^{6} \mathrm{CFU} \cdot \mathrm{g}^{-1}$ probiotics (T2), yet the differences between T1 group and control was negligible. Similarly, Wang et al. (2008) have reported that the myeloperoxidase (MPO) activity of tilapia increased after 40 days of rearing in water containing the Enteroccus faecium probiotic. In contrast, serum peroxidase activity in rainbow trout fed with $B$. subtilis remained unchanged (NewajFyzul et al. 2007). Additionally, peroxidase contents in the serum and head kidney leucocytes of gilthead seabream, Sparus aurata, did not considerably vary during four weeks of dietary administration of probiotics (Díaz-Rosales et al. 2006). The plasma peroxidase activity is usually measured as indicator of leucocytes activity (Quade and Roth 1997). It has been shown that dietary administration of probiotics can remarkably enhance the phagocytosis activity of fish head kidney leucocytes (Panigrahi et al. 2004). Accordingly, the increased peroxidase activity recorded in this study could be due to higher phagocytic activity of leucocytes accompanied by an increased respiratory burst activity, and thus an increase need to detoxify the peroxide produced.

Lysozyme as a bactericidal enzyme is an important component of the non-specific humoral defense system of fish. Lysozyme is released by leucocytes and reacts against both gram-positive and gram-negative bacteria (Saurabh and Sahoo 2008). The variation of lysozyme activity depends on several factors such as nutritional status, seasonal variation, sex and sexual maturation, salinity, $\mathrm{pH}$, water temperature, stress, and infections (Saurabh and Sahoo 2008). In the presently reported study, the plasma lysozyme activity of fish in the various treatments was not significantly affected by dietary probiotics, albeit the amount of plasma lysozyme activity in probiotic treatments was noticeably higher than that of the control group. Similarly, administration in the rearing water of either 
Enteroccus faecium or Bacillus spp. probiotics did not significantly change the level of lysozyme activity in tilapia (Wang et al. 2008, Zhou et al. 2010). On the contrary, the dietary administration of Bacillus strains markedly elevated the serum lysozyme activity of rainbow trout (Brunt et al. 2007, Newaj-Fyzul et al. 2007, Sharifuzzaman and Austin 2009); furthermore, an increase in the lysozyme activity of tilapia (Aly et al. 2008) and olive flounder, Paralichthys olivaceus (Temminck et Schlegel, 1846) (see Harikrishnan et al. 2010), has been reported after the dietary administration of Bacillus and Lactobacillus probiotics. Sun et al. (2010) have demonstrated that the serum lysozyme activity of orange-spotted grouper, Epinephelus coioides (Hamilton, 1822), was enhanced after 60 days of feeding with probiotics, whereas no significant difference between the treatments was observed after 30 days of dietary administration. Apparently, the influence of probiotics on fish serum lysozyme activity could depend on the duration and dose of administration, bacterial strains and experimental conditions and the differences observed here may become significant after prolongedadministration periods.

Complement is an efficient mechanism of the fish immune system, which results in the killing of microorganisms through lysis of their cellular membranes (Ellis 1999). In the presently reported research project, the amount of alternative complement (ACH50) did not significantly vary between treatments. However, the highest value of ACH50 was observed in T1 treatment. Similarly, the variations of $\mathrm{ACH} 50$ in rainbow trout and gilthead seabream fed different levels of probiotics were not statistically significant (Díaz-Rosales et al. 2006, Newaj-Fyzul et al. 2007). On the other hand, the value of ACH50 in Nile tilapia and olive flounder considerably increasedby either immersion or dietary administration of probiotics (Aly et al. 2008, Wang et al. 2008, Harikrishnan et al. 2010). Moreover, the dietary administration of $B$. pumilus or $B$. clausii containing diets could activate the complement system $\left(\mathrm{C}_{3}\right.$ and $\left.\mathrm{C}_{4}\right)$ of grouper, Epinephelus coioides, after 30 days of feeding, but no significant difference in serum complement $\mathrm{C}_{3}$ and $\mathrm{C}_{4}$ levels were observed between the treatments and the control after 60 days of feeding (Sun et al. 2010). The duration of probiotic administration must therefore be determined for each fish species for the dietary treatment to be an efficient immunostimulant.

In this study, the plasma bactericidal activity against a Gram-negative bacterial strain of fish fed with $1 \times 10^{6}$ $\mathrm{CFU} \cdot \mathrm{g}^{-1}$ diet significantly increased compared to that of control fish. Similarly, the serum bactericidal activity of Indian major carp and rainbow trout fed B. subtilis noticeably improved after 2 weeks of feeding (Newaj-Fyzul et al. 2007, Kumar et al. 2008). Aly et al. (2008) have reported that both bactericidal activity and resistance to the bacterial challenge of Aeromonas hydrophila were enhanced in Nile tilapia, Oreochromis niloticus, fed B. subtilis and Lactobacillus acidophilus. An improvement in the resistance of fish to bacterial infection by the dietary administration of probiotics has been reportedin several studies (Kesarcodi-
Watson et al. 2008, Nayak 2010). In the the effective large antimicrobial arsenal in the serum of tinfoil barb potentially enhancing the fish resistance to bacterial infections.

Probiotics are reported to modulate fish immune responses and resistance to pathogens through stimulation of antibody secreting cell response, induction of phagocytosis activity, modification of cytokine production, and natural complement activity (Panigrahi et al. 2004, 2007, Ringø et al. 2012). The improved immune parameters (plasma antiprotease and peroxidase activities) of fish fed graded levels of dietary probiotics in this study could be due to higher secretion of antibodies and activation of leucocytes phagocytic activity in fish fed dietary probiotics. Correspondingly, the enhancement of natural immunity in the fish serum (significantly higher level of bactericidal activity in T2 and slight enhancement of other antibacterial components of serum such as lysozyme and complement activities) can correspond to an improvement of fish resistance to pathogens. Hence, this stronger bactericidal activity in T2 can be caused by higher stimulation of the antibacterial arsenal of fish by dietary bacterial probiotics.

It can be concluded from the the presently reported study that all non-specific immune parameters tested in tinfoil barb, Barbonymus schwanenfeldii, were enhanced to some extent, by the dietary administration of Bacillus probiotics, although the observed changes were not always significant. The strongest effect of dietary probiotics was observed in fish fed the $1 \times 10^{6} \mathrm{CFU} \mathrm{\textrm {g } ^ { - 1 }}$ diet (T2). This dosage of Bacillus probiotics can enhance the immune responses of this species after 2 weeks of dietary administration. Further study should focus on the effect of this dietary bacterial concentration on the fish response to bacterial and parasitical challenges in order to test its potential protective effect against the common pathogens of tinfoil barb. Furthermore, longer administration periods should be studied and the expression of immune-related genes be included in order to check if the immune system of tinfoil barb is not burdened by a long-term dietary administration of probiotics and to elucidate the mechanisms of immunomodulation. Additionally, further study should be conducted on the gastrointestinal tract and digestive system of tinfoil barb in response to dietary probiotics.

\section{ACKNOWLEDGEMENTS}

The authors are truly grateful to Mr. Rasa and the microbiology laboratory at the faculty of science of the University of Guilan and to Amin Lab. Special thanks are also given to M. Ostovari, M. Maleki, A. Mohamadpour, and M. Gholami who kindly contributed to the completion of the study.

\section{REFERENCES}

Adams C.A. 2010. The probiotic paradox: Live and dead cells are biological response modifiers. Nutrition Research Reviews 23 (1): 37-46. DOI: 10.1017/S0954422410000090

Aly S.M., Ahmed Y.A.-G., Ghareeb A.A.-A., Mohamed M.F. 2008. Studies on Bacillus subtilis and Lactobacillus acidophilus, as potential probiotics, on the immune response 
and resistance of Tilapia nilotica (Oreochromis niloticus) to challenge infections. Fish and Shellfish Immunology 25 (1-2): 128-136. DOI: 10.1016/j.fsi.2008.03.013

Anonymous 2002. Guidelines for the evaluation of probiotics in food. Food and Agriculture Organization of the United Nations and World Health Organization. London, Ontario, Canada.

Bailey R., Cole B. 1999. Spawning the tinfoil barb, Barbodes schwanenfeldi in Hawaii. Aquafarmer Information Sheet. Publication No. 136. Center for Tropical and Subtropical Aquaculture. University of Hawaii, Honolulu, HI, USA

Bassleer G. 1997. Color guide of tropical fish diseases: on freshwater fish. Bassleer Biofish, Westmeerbeek, Belgium.

Bradford M.M. 1976. A rapid and sensitive method for the quantification of microgram quantities of protein utilizing the principle of protein-dye binding. Analytical Biochemistry 72 (1-2): 248-254. DOI: 10.1016/00032697(76)90527-3

Bricknell I., Dalmo R.A. 2005. The use of immunostimulants in fish larval aquaculture. Fish and Shellfish Immunology 19 (5): 457-472. DOI: 10.1016/j.fsi.2005.03.008

Brunt J., Hansen R., Jamieson D.J., Austin B. 2008. Proteomic analysis of rainbow trout (Oncorhynchus mykisss, Walbaum) serum after administration of probiotics in diets. Veterinary Immunology and Immunopathology 121 (3-4): 199-205. DOI: 10.1016/j.vetimm.2007.09.010

Brunt J., Newaj-Fyzul A., Austin B. 2007. The development of probiotics for the control of multiple bacterial diseases of rainbow trout, Oncorhynchus mykiss (Walbaum). Journal of Fish Diseases 30 (10): 573-579. DOI: 10.1111/j.13652761.2007.00836.x

Cha S.-H., Lee J.-S., Song C.-B., Lee K.-J., Jeon Y.-J. 2008. Effects of chitosan-coated diet on improving water quality and innate immunity in the olive flounder, Paralichthys olivaceus. Aquaculture 278 (1-4): 110-118. DOI: 10.1016/j.aquaculture.2008.01.025

Cutting S.M. 2011. Bacillus probiotics. Food Microbiology 28 (2): 214-220. DOI: 10.1016/j.fm.2010.03.007

Díaz-Rosales P., Salinas I., Rodríguez A., Cuesta A., Chabrillón M., Balebona M.C., Moriñigo M.Á., Esteban M.Á., Meseguer J. 2006. Gilthead seabream (Sparus aurata L.) innate immune response after dietary administration of heatinactivated potential probiotics. Fish and Shellfish Immunology 20 (4): 482-492. DOI: 10.1016/j.fsi.2005.06.007

Ellis A.E. 1999. Immunity to bacteria in fish. Fish and Shellfish Immunology 9 (4): 291-308. DOI: 10.1006/fsim.1998.0192

Gante H.F., Moreira da Costa L., Micael J., Alves M.J. 2008. First record of Barbonymus schwanenfeldii (Bleeker) in the Iberian Peninsula. Journal of Fish Biology 72 (4): 1089-1094. DOI: 10.1111/j.1095-8649.2007.01773.x

Gatesoupe F.J. 1999. The use of probiotics in aquaculture. Aquaculture 180 (1-2): 147-165. DOI: 10.1016/S00448486(99)00187-8

Gatesoupe F.-J. 2008. Updating the importance of lactic acid bacteria in fish farming: Natural occurrence and probiotic treatments. Journal of Molecular Microbiology and Biotechnology 14 (1-3): 107-114. DOI: 10.1159/ 000106089
Harikrishnan R., Balasundaram C., Heo M.-S. 2010. Effect of probiotics enriched diet on Paralichthys olivaceus infected with lymphocystis disease virus (LCDV). Fish and Shellfish Immunology 29 (5): 868-874. DOI: 10.1016/j.fsi.2010.07.031

Irianto A., Austin B. 2002. Use of probiotics to control furunculosis in rainbow trout, Oncorhynchus mykiss (Walbaum). Journal of Fish Diseases 25 (6): 333-342. DOI: 10.1046/j.1365-2761.2002.00375.x

Kesarcodi-Watson A., Kaspar H., Lategan M.J., Gibson L. 2008. Probiotics in aquaculture: The need, principles and mechanisms of action and screening processes. Aquaculture 274 (1): 1-14. DOI: 10.1016/j.aquaculture.2007.11.019

Kim D.-H., Austin B. 2006. Innate immune responses in rainbow trout (Oncorhynchus mykiss, Walbaum) induced by probiotics. Fish and Shellfish Immunology 21 (5): 513-524. DOI: $10.1016 /$ j.fsi.2006.02.007

Kiron V. 2012. Fish immune system and its nutritional modulation for preventive health care. Animal Feed Science and Technology 173 (1-2): 111-133. DOI: 10.1016/ j.anifeedsci.2011.12.015

Kumar R., Mukherjee S.C., Ranjan R., Nayak S.K. 2008. Enhanced innate immune parameters in Labeo rohita (Ham.) following oral administration of Bacillus subtilis. Fish and Shellfish Immunology 24 (2): 168-172. DOI: 10.1016/j.fsi.2007.10.008

Kumar S., Sahu N.P., Pal A.K., Choudhury D., Yengkokpam S., Mukherjee S.C. 2005. Effect of dietary carbohydrate on heamatology, respiratory burst activity and histological chenge in L. rahita juveniles. Fish and Shellfish Immunology 19 (4): 331-334. DOI: 10.1016/j.fsi.2005.03.001

Maeda M., Nogami K., Kanematsu M., Hirayama K. 1997. The concept of biological control methods in aquaculture. Hydrobiologia 358 (1-3): 285-290. DOI: 10.1023/ A:1003126129709

Magnadóttir B. 2006. Innate immunity of fish (overview). Fish and Shellfish Immunology 20 (2): 137-151. DOI: 10.1016/j.fsi.2004.09.006

Magnadóttir B., Jónsdóttir H., Helgason S., Björnsson B., Jørgensen T.Ø., Pilström L. 1999. Humoral immune parameters in Atlantic cod (Gadus morhua L.): The effects of environmental temperature. Comparative Biochemistry and Physiology Part B: Biochemistry and Molecular Biology 122 (2): 173-180. DOI: 10.1016/S0305-0491 (98)10156-6

Merrifield D.L., Dimitroglou A., Foey A., Davies S.J., Baker R.T.M., Bøgwald J., Castex M., Ringo E. 2010. The current status and future focus of probiotic and prebiotic applications for salmonids. Aquaculture 302 (1-2): 1-18. DOI: 10.1016/j.aquaculture.2010.02.007

Nayak S.K. 2010. Probiotics and immunity: A fish perspective. Fish and Shellfish Immunology 29 (1): 2-14. DOI: 10.1016/j.fsi.2010.02.017

Nayak S.K., Swain P., Mukherjee S.C. 2007. Effect of dietary supplementation of probiotic and vitamin $\mathrm{C}$ on the immune response of Indian major carp, Labeo rohita (Ham.). Fish and Shellfish Immunology 23 (4): 892-896. DOI: 10.1016/j.fsi.2007.02.008 
Newaj-Fyzul A., Adesiyun A.A., Mutani A., Ramsubhag A., Brunt J., Austin B. 2007. Bacillus subtilis AB1 controls Aeromonas infection in rainbow trout (Oncorhynchus mykiss, Walbaum). Journal of Applied Microbiology 103 (5): 1699-1706. DOI: 10.1111/j.1365-2672.2007.03402.x

Nicholson J.P., Wolmarans M.R., Park G.R. 2000. The role of albumin in critical illness. British Journal of Anaesthesia 85 (4): 599-610. DOI: $10.1093 / \mathrm{bja} / 85.4 .599$

Nikoskelainen S., Ouwehand A.C., Bylund G., Salminen S., Lilius E.-M. 2003. Immune enhancement in rainbow trout (Oncorhynchus mykiss) by potential probiotic bacteria (Lactobacillus rhamnosus). Fish and Shellfish Immunology 15 (5): 443-452. DOI: 10.1016/S1050-4648(03)00023-8

Ortuno J., Esteban M.A., Mulero V., Meseguer J. 1998. Methods for studying the haemolytic, chemoattractant and opsonic activities of seabream (Sparus aurata L.) serum. Pp: 97-100. In: Barnes A.C., Davidson G.A., Hiney M.P., McIntosh D. (eds.) Methodology in fish disease research. Fisheries Research Services, Aberdeen, Scotland.

Panigrahi A., Kiron V., Kobayashi T., Puangkaew J., Satoh S., Sugita H. 2004. Immune responses in rainbow trout Oncorhynchus mykiss induced by a potential probiotic bacteria Lactobacillus rhamnosus JCM 1136. Veterinary Immunology and Immunopathology 102 (4): 379-388. DOI: 10.1016/j.vetimm.2004.08.006

Panigrahi A., Kiron V., Satoh S., Hirono I., Kobayashi T., Sugita H., Puangkaew J., Aoki T. 2007. Immune modulation and expression of cytokine genes in rainbow trout Oncorhynchus mykiss upon probiotic feeding. Developmental and Comparative Immunology 31 (4): 372-382. DOI: 10.1016/j.dci.2006.07.004

Qi Z., Zhang X.-H., Boon N., Bossier P. 2009. Probiotics in aquaculture of China - current state, problems and prospect. Aquaculture 290 (1-2): 15-21. DOI: 10.1016/ j.aquaculture.2009.02.012

Quade M.J., Roth J.A. 1997. A rapid, direct assay to measure degranulation of bovine neutrophil primary granules. Veterinary Immunology and Immunopathology 58 (3-4): 239-248. DOI: 10.1016/S0165-2427(97)00048-2

Rao Y.V., Das B.K., Jyotyrmayee P., Chakrabarti R. 2006. Effect of Achyranthes aspera on the immunity and survival of Labeo rohita infected with Aeromonas hydrophila. Fish and Shellfish Immunology 20 (3): 263-273. DOI: 10.1016/j.fsi.2005.04.006

Rengpipat S., Phianphak W., Piyatiratitvorakul S., Menasveta P. 1998. Effects of probiotic bacterium on black tiger shrimp Penaeus monodon survival and growth. Aquaculture 167 (3-4): 301-313. DOI: 10.1016/S00448486(98)00305-6

Ringø E., Olsen R.E., Vecino J.L.G., Wadsworth S., Song S.K. 2012. Use of immunostimulants and nucleotides in aquaculture: a review. Journal of Marine Science: Research and Development 2 (1): [22 pages] DOI: 10.4172/21559910.1000104

Rodríguez A., Cuesta A., Ortuño J., Esteban M.A., Meseguer J. 2003. Immunostimulant properties of a cell wall-modified whole Saccharomyces cerevisiae strain administered by diet to seabream (Sparus aurata L.).
Veterinary Immunology and Immunopathology 96 (3-4): 183-192. DOI: 10.1016/S0165-2427(03)00164-8

Sakai M. 1999. Current research status of fish immunostimulants. Aquaculture 172 (1-2): 63-92. DOI: 10.1016/S00448486(98)00436-0

Salinas I., Cuesta A., Esteban M.Á., Meseguer J. 2005. Dietary administration of Lactobacillus delbrüeckii and Bacillus subtilis, single or combined, on gilthead seabream cellular innate immune responses. Fish and Shellfish Immunology 19 (1): 67-77. DOI: 10.1016/j.fsi.2004.11.007

Saurabh S., Sahoo P.K. 2008. Lysozyme: an important defence molecule of fish innate immune system. Aquaculture Research 39 (3): 223-239. DOI: 10.1111/j.13652109.2007.01883.x

Sharifuzzaman S.M., Austin B. 2009. Influence of probiotic feeding duration on disease resistance and immune parameters in rainbow trout. Fish and Shellfish Immunology 27 (3): 440-445. DOI: 10.1016/j.fsi.2009.06.010

Son V.M., Chang C.-C., Wu M.-C., Guu Y.-K., Chiu C.-H., Cheng W. 2009. Dietary administration of the probiotic, Lactobacillus plantarum, enhanced the growth, innate immune responses, and disease resistance of the grouper Epinephelus coioides. Fish and Shellfish Immunology 26 (5): 691-698. DOI: 10.1016/j.fsi.2009.02.018

Sun Y.-Z., Yang H.-L., Ma R.-L., Lin W.-Y. 2010. Probiotic applications of two dominant gut Bacillus strains with antagonistic activity improved the growth performance and immune responses of grouper Epinephelus coioides. Fish and Shellfish Immunology 29 (5): 803-809. DOI: 10.1016/j.fsi.2010.07.018

Tripathi B.D., Govil S.R. 2001. Water pollution (An experimental approach). CBS Publishers and Distributors, New Delhi, India.

Wang Y.-B., Tian Z.-Q., Yao J.-T., Li W.-f. 2008. Effect of probiotics, Enteroccus faecium, on tilapia (Oreochromis niloticus) growth performance and immune response. Aquaculture 277 (3-4): 203-207. DOI: 10.1016/ j.aquaculture.2008.03.007

Yanar M., Erçen Z., Özlüer Hunt A., Büyükçapar H.M. 2008. The use of alfalfa, Medicago sativa as a natural carotenoid source in diets of goldfish, Carassius auratus. Aquaculture 284 (1-4): 196-200. DOI: 10.1016/ j.aquaculture.2008.07.050

Zhou X., Tian Z., Wang Y., Li W. 2010. Effect of treatment with probiotics as water additives on tilapia (Oreochromis niloticus) growth performance and immune response. Fish Physiology and Biochemistry 36 (3): 501-509. DOI: 10.1007/s10695-009-9320-Z

Zuo X., Woo P.T.K. 1997. Natural anti-proteases in rainbow trout, Oncorhynchus mykiss and brook charr, Salvelinus fontinalis and the in vitro neutralization of fish $\alpha 2$-macroglobulin by the metalloprotease from the pathogenic haemoflagellate, Crytobia salmositica. Parasitology 114 (4): 375-381. DOI: 10.1017/S0031182096008578

Received: 1 April 2013

Accepted: 23 July 2013

Published electronically: 30 June 2013 